\title{
Current Status of and Challenges in Regional Policies in Japan
}

\section{Współczesny status japońskiej polityki regionalnej i stojące przed nią wyzwania}

\author{
Munenori Ichishima \\ FACULTY OF POLICY STUdIES \\ IWATE PREFECTURAL UNIVERSITY \\ TAKIZAWA CITY, IWATE PREFECTURE, JAPAN \\ mune_i@iwate-pu.ac.jp
}

\begin{abstract}
This study aims to explain current regional policies in Japan and to explore challenges in relation to the same. Specifically, I will focus on regional revitalisation policies implemented by the Abe cabinet since 2014 and examine whether grants for regional revitalisation policies are distributed in a way that political scientists have disputed for a long time. From the perspective of public policy analyses in political science, I will conduct statistical analyses by using aggregated data of local municipalities in Japan. Thus, I will clarify the current status of and challenges related to regional policies in Japan.
\end{abstract}

\begin{abstract}
Abstrakt
Artykuł ma na celu wyjaśnienie współczesnych kierunków i tendencji działań regionalnych $w$ Japonii wraz z przedstawieniem towarzyszących im wyzwań. W szczególności, tekst uwypukla politykę rewitalizacji regionalnej wdrożonej przez rząd Abe w roku 2014. Analizowane są także działania i decyzje związane z podziałami środków oraz ich zasadność naukowoekonomiczna. Służyć temu będą analizy wzbogacone o dane statystyczne uzyskane $\mathrm{z}$ ośrodków japońskich. Pozwoli to określić współczesny status polityki oraz wyzwań, przed którymi w tym zakresie staje obecnie Japonia.
\end{abstract}




\section{Introduction}

According to the Japanese Ministry of Land, Infrastructure, Transport and Tourism, the population of Japan peaked at approximately 127.8 million in 2005 and has begun decreasing. The ministry estimates that Japan's population will reach approximately 95.2 million in $2050^{1}$. Moreover, on investigating changes of population movements in Japan in 2017, only the Tokyo Metropolitan Area ${ }^{2}$ became overrun by new residents, about 120,000 people. In other areas, the number of residents moving out was more than that of people moving in. For instance, the Osaka Area, which was the second largest urban area in Japan ${ }^{3}$, witnessed a decrease of approximately 9,000 people 4 . In addition, it appears that about $58.4 \%$ of residents moving in the Tokyo Metropolitan Area were aged 20-24 years, and about $23.5^{2}$ were aged $15^{-19}$ years in 20165. The former generation was of people seeking employment, and the latter was of those enrolling in university. Thus, much of the younger generation moves in the Tokyo Metropolitan Area from all over the country to get jobs or get admitted in universities. According to the Ministry of Land, Infrastructure, Transport and Tourism, approximately $20 \%$ of areas where people live in the present day will no longer be occupied by $2050^{6}$.

Owing to the aforementioned situation in Japan, regional revitalisation policies have been implemented alongside the second Abe cabinet, which took office in September 2014, and since the revised budget for fiscal year 2014, the Japanese government has distributed grants for regional revitalisation to local municipalities.

This study aims to clarify where these grants are distributed and confirm whether theories of conventional distribution of grants-in-aid in Japan apply to grants for regional revitalisation. Local finance in Japan is too centralised and, thus, does not allow municipalities to be financially independent from the national government. Therefore, it is so difficult for local governments to promote their own policies without the support of grants-in-aid from the central government.

\footnotetext{
1 Ministry of Land, Infrastructure, Transport and Tourism, http://www.mlit.go.jp/common/o00135838.pdf [access: 11 July 2018]

2 Tokyo Prefecture, Saitama Prefecture, Chiba Prefecture and Kanagawa Prefecture. 3 Osaka Prefecture, Kyoto Prefecture, Hyogo Prefecture and Nara Prefecture.

4 Statistics Japan, https://www.stat.go.jp/data/idou/2017np/kihon/youyaku/index.html [access: 11 July 2018]

5 Headquarter for Overcoming Population Decline and Vitalizing Local Economy in Japan in Cabinet Secretariat, https://www.kantei.go.jp/jp/singi/sousei/meeting/kpi_kenshouteam/h29-10-o6shiryou2.pdf [access: 11 July 2018]

6 Ministry of Land, Infrastructure, Transport and Tourism, http://www.mlit.go.jp/common/o00135838.pdf [access: 11 July 2018]
} 


\section{Munenori Ichishima: Current Status of and Challenges in Regional Policies in Japan}

\section{Regional revitalisation policies in Japan}

Regional revitalisation policies in Japan basically aim to revitalise local municipalities and to solve declining population issues. Specifically, they present the following three points as medium- to long-term aims of regional revitalisation policies: 1) to realise the desires of the younger generation in terms of employment, marriage and child care; 2 ) to improve excessive population concentration to the Tokyo Metropolitan Area and 3) to resolve local problems as applicable to the characteristics of the concerned region.

To this end, regional revitalisation policies in Japan are presented in the following five policy areas: to encourage new streams of people towards local areas; to create flexible jobs in local areas; to realise the needs of married life, birth and child care in relation to the younger generation; to develop the concerned areas and increase safety and to promote regional cooperation?.

For instance, regional revitalisation policies in Ofunato City in Iwate Prefecture focus on processing and distributing low-value materials which have not been industrialised and high value adding materials which a catch of fish is too small. In addition to this, guard lodges have been established to interest consumers to visit fish-producing districts and interact with fishermen and to promote sightseeing. Owing to such regional revitalisation policies, Ofunato City could create flexible jobs locally and encourage new streams of people towards local areas ${ }^{8}$.

Similarly, in Shiwa Town in Iwate Prefecture, the induction of investment was entrusted to private-sector businesses instead of carrying on in-house development although the town as the local government was the landowner. As a result, the town could established a base with several institutions which had the ability to attract customers owing to the market mechanisms pursued by private businesses and could raise funds for development from the market. Thus, Shiwa Town could not only create flexible jobs in local areas and encourage new streams of people towards local areas such as Ofunato City but also develop

\footnotetext{
7 Headquarter for Overcoming Population Decline and Vitalizing Local Economy in Japan in Cabinet Secretariat, https://www.kantei.go.jp/jp/singi/sousei/meeting/honbukaigou/h26-09-12-siryou2.pdf [access: 11 July 2018]

8 Headquarter for Overcoming Population Decline and Vitalizing Local Economy in Japan in Cabinet Secretariat and Headquarter for Promotion of Regional Revitalization in Cabinet Office, https://www.kantei.go.jp/jp/singi/sousei/pdf/chihousousei_jireisyu.pdf [access: 20 July 2019]
} 
the concerned areas, increase safety and promote regional cooperation because of this regional revitalisation policy9.

\section{Literature review on the distribution of grants}

Conventionally, much research exists on grants-in-aid. In political science, this research is normally conducted from the perspective of political distribution of grants. Theoretically, political scientists have argued that the distribution occurs in political business cycle or pork barrel politics. The former view theorises that politicians intervene in the economy for ruling parties to win national elections; the latter theorises that politicians distribute profits through roads, bridges, the Shinkansen and so on - all by means of grants-in-aid to their constituencies.

There are several studies that explain the political distribution of grants-in-aid. For instance, Fujimoto et al. (1983) demonstrate political influence on the distribution of agricultural budget to prefectures from the perspective of numerous local variables and number of members of the Diet. Chiu (1993) has taken up a subsidy to public undertakings to prefectures, researched on the association of the difference of votes between the ruling party and opposition parties and the distribution of grants-in-aid and has posited that the ruling party has distributed many grants-in-aid to prefectures with a distinct difference between the votes for the ruling and the opposition parties; moreover, the weight of the votes was heavy. Hori (1996) showed that the number of members of the Diet belonging to the ruling party and the number of times they were elected influenced the distribution of the budget of public undertakings. Kobayashi (1997) has also proven that there is political noise, such as career points and rates of the votes of members of the Diet belonging to the ruling party, in terms of the distribution of grants. Doi and Ashiya (1997) and Doi (2000) have mentioned that many grants-in-aid are distributed to prefectures in which many members of the Diet are elected. Onizuka (1997) has analysed factors involved in the distribution of grants-in-aid and subsidy to prefectures and have revealed that the degree of a close election has come to influence this distribution since the beginning of the 1980 s.

However, the number of studies on the distribution of grants in Japan has declined since the 2000s. This decrease can be attributed to the fact that the condition of public finance in Japan has changed according to the appearance of the Koizumi cabinet, which carried out fiscal reform very strictly.

9 Headquarter for Overcoming Population Decline and Vitalizing Local Economy in Japan in Cabinet Secretariat and Headquarter for Promotion of Regional Revitalization in Cabinet Office, https://www.kantei.go.jp/jp/singi/sousei/pdf/chihousousei_jireisyu.pdf [access: 20 July 2019] 
Munenori Ichishima: Current Status of and Challenges in Regional Policies in Japan

\section{Preceding studies about regional revitalisation policies}

Currently, there are three categories of preceding studies about regional revitalisation policies. The first category discusses the content of regional revitalisation policies in various local autonomies in Japan. For instance, Takayose (2015) discusses regional revitalisation policies from the perspective of reform of grants-in-aid. Nakayama (2016) considers regional revitalisation policies in relation to population decline. Kaneko (2016) looks at regional revitalisation policies from the perspective of sociology. Yaoita (2017) also discusses regional revitalisation policies as a package of policies. The second category introduces methods and cases of regional revitalisation policies in Japan. For instance, Hashimoto (2015) discusses methods of regional vitalisation and Nakato (2016) discusses methods of regional revival in depopulated areas. The third category focuses on international regional revitalisation policies such as those proposed by the Centre of Area Studies in Hosei University and Okamoto (2017), who describe the mechanism of regional vitalisation in the European Union.

\section{Research questions}

As mentioned previously, regional revitalisation policies in Japan have just begun to be implemented, and there have not been any macroscopic studies conducted on this subject thus far. Therefore, I will analyse the distribution of grants for regional revitalisation policies from a macroscopic perspective.

This study attempts to answer the following research questions: Where are grants of regional revitalisation policies distributed? Does the distribution of grants for regional revitalisation policies apply to theories of preceding studies on the distribution of grants-in-aid in Japan?

\section{Analysis}

To answer the above research questions, I conducted a structural equation modelling (SEM) analysis, clarifying what kinds of factors influence the distribution of grants for regional revitalisation policies. In this analysis, I have regarded the following as the theories of previous studies on the distribution of grants-in-aid in Japan: 1) the worse the local finance trend, the more the local municipalities can be distributed grants-in-aid; 2) the worse the social and economic trends-that is, the decreasing population and higher unemployment trends-the more the local municipalities can be distributed grants-in-aid and 3) the more the vote rate of ruling parties, the more the local municipalities can be distributed grants-in-aid. 
Subjects of this analysis were 773 cities and 23 special wards in Tokyo prefecture. The dependent variable of this analysis was the amount of grants for regional revitalisation policies per capita ${ }^{10}$. Observational variables were as follows: rate of votes obtained by ruling parties ${ }^{11}$, population trend ${ }^{12}$, local finance trend ${ }^{13}$, ratio of secondary industries' working population ${ }^{14}$, unemployment ratio ${ }^{15}$ and home ownership ratio ${ }^{16}$.

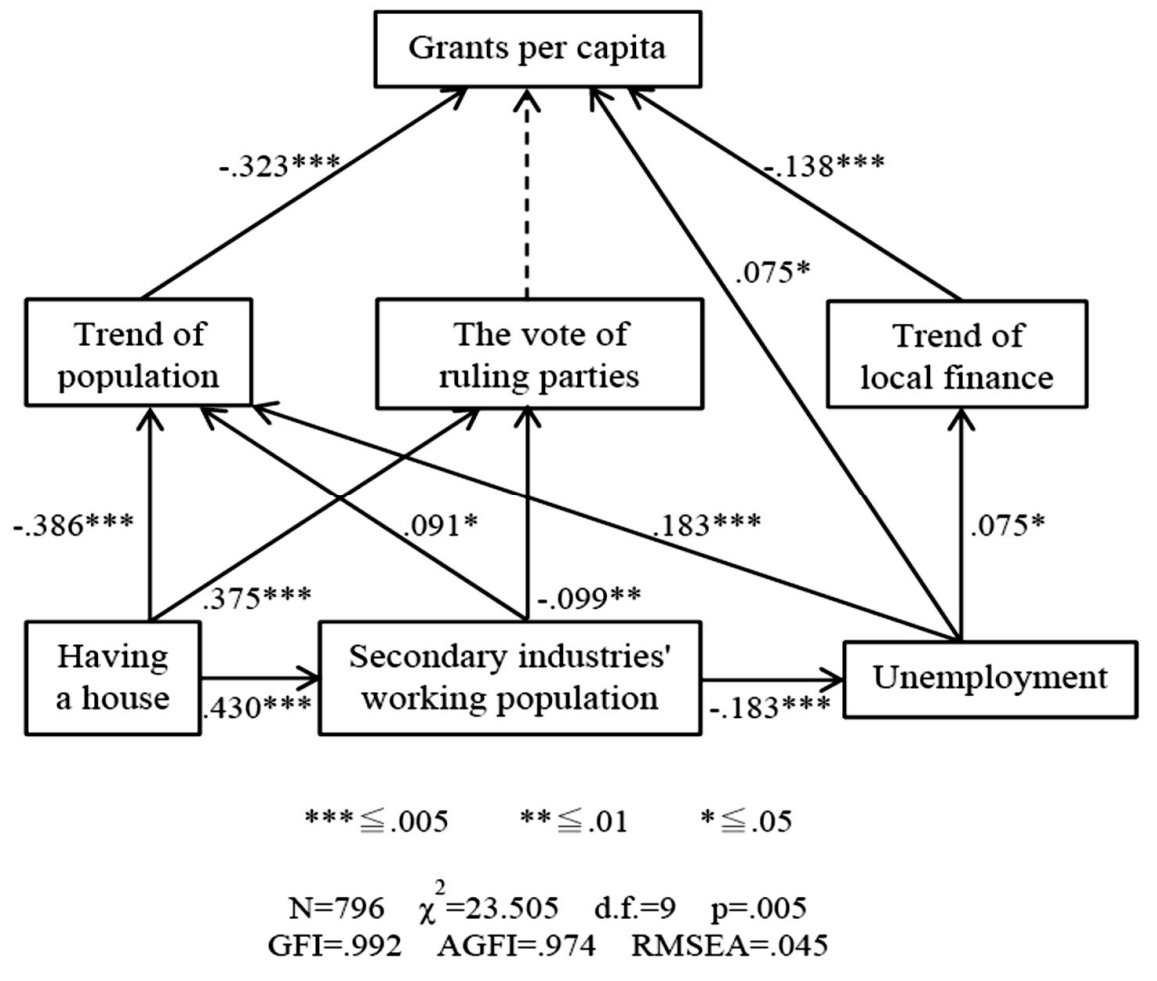

Fig. 1: Results of the SEM: Model of distribution of grants for regional revitalisation policies

10 Data from Cabinet Secretariat and Cabinet Office, https://www.kantei.go.jp/jp/singi/sousei/about/kouhukin/index.html [access: 1 May 2018]

11 The percentage of the vote obtained by ruling parties in proportional representation at the election of the House of Representatives in 2014. Data from The Asahi Shimbun Company. 2014. Asahi Shimbun de Miru 2014 Sosenkyo no Subete. The Asahi Shimbun Company.

12 Population in 2015/population in 2005. Data from Statistics Japan, https://www.estat.go.jp/ [access: 1 May 2018]

13 Financial index in 2015/ financial index in 2005. Data from Ministry of Internal Affairs and Communications, http://www.soumu.go.jp/iken/kessan_jokyo_2.html [access: 1 May 2018]

14 Data from Statistics Japan, https://www.e-stat.go.jp [access: 1 May 2018]

15 Data from Statistics Japan, https://www.e-stat.go.jp [access: 1 May 2018]

16 Data from Statistics Japan, https://www.e-stat.go.jp [access: 1 May 2018] 


\section{Munenori Ichishima: Current Status of and Challenges in Regional Policies in Japan}

Figure 1 demonstrates the analysis results. The results re-veal that as population decreases, local finance worsens, and at the same time, when the unemployment ratio is high, the amount of grants for regional revitalisation policies at $5 \%$ level of significance is higher. Furthermore, the rate of votes obtained by ruling parties positively influences grants but is not statistically significant at the $5 \%$ level ${ }^{17}$.

Thus, grants for regional revitalisation policies are distributed to local municipalities wherein population decreases, local finance worsens and the unemployment ratio is high. As a result, the distribution of grants for regional revitalisation policies does not apply to the theories of preceding studies on the distribution of grants-in-aid in Japan.

Now, I will consider why grants for regional revitalisation policies do not apply to the theories of preceding studies on distribution of grantsin-aid in Japan. Apparently, the most important reason is that the conditions under which the grants for regional revitalisation policies are applied are very severe. For instance, conditions to grant subsidies for regional revitalisation policies are that they have to be pioneering projects and have to set up objective key performance indicator(s) aiming at the outcome in favour of residents.

Table 1: Distributed grants for regional revitalisation policies ${ }^{18}$

\begin{tabular}{|c|c||c|c||c||c|}
\hline $\begin{array}{c}\text { Grants for } \\
\text { regional } \\
\text { revitalisation } \\
\text { policies }\end{array}$ & $\begin{array}{c}\text { Fiscal } \\
\text { year }\end{array}$ & Prefectures & $\begin{array}{c}\text { Cities, towns } \\
\text { and villages }\end{array}$ & Total & Target \\
\hline \hline Prevenient & 2014 & 11.0 & 19.3 & 30.3 & 30 \\
\hline Accelerating & 2015 & 29.6 & 68.9 & 98.5 & 100 \\
\hline $\begin{array}{c}\text { Pushing } \\
\text { forward }\end{array}$ & 2016 & 13.1 & 10.6 & 23.8 & 100 \\
\cline { 2 - 6 } & 2017 & 6.9 & 8.6 & 15.3 & 100 \\
\hline $\begin{array}{c}\text { Developing } \\
\text { bases }\end{array}$ & 2016 & 26.0 & 40.3 & 66.3 & 90 \\
\hline
\end{tabular}

As a result of these conditions, it is difficult for local municipalities to apply for grants for regional revitalisation policies. Consequently, as Table 1 shows, the total amounts of grants for regional revitalisation policies have suddenly decreased since the introduction of pushing forward grants for regional revitalisation policies in the 2016 fiscal year. In the 2014 fiscal year, 30.3 billion yen was distributed as prevenient grants for regional revitalisation policies against the target grants-in-aid amount of 30 billion yen. In the 2015 fiscal year, 98.5 billion yen was

17 This is statistically significant at $6.5 \%$ level.

18 Data from Cabinet Secretariat and Cabinet Office, https://www.kantei.go.jp/jp/singi/sousei/about/kouhukin/index.html [access: 1 May 2018] 
distributed as accelerating grants for regional revitalisation policies against the target amount of 100 billion yen.

However, in the 2016 fiscal year, only 23.8 billion yen was distributed as pushing forward grants for regional revitalisation policies against a target amount of 100 billion yen. In the 2017 fiscal year, the distributed amount of grants was only 15.3 billion yen, although the target amount was 100 billion yen. Similarly, 66.3 billion yen was distributed as developing bases grants for regional revitalisation policies against the target amount of 90 billion yen in the 2016 fiscal year.

Thus, eligibility conditions for grants for regional revitalisation policies are too strict for local municipalities to apply. As a result, the number of local municipalities applying for these grants has gradually decreased. Consequently, a large number of grants for regional revitalisation policies has not yet been distributed. Considering this, the grants that have not been distributed politically is a matter of course.

Furthermore, equally important is analysing the cases of towns and villages in small, local municipalities. This indicates different results compared to those of the analysis above, as it is more difficult for small towns and villages to apply for these grants. In this vein, we need to examine what kinds of factors influence the distribution of grants for regional revitalisation policies. It appears that civil servant loans from the central government to local governments might affect applications, as it is difficult to apply for them as well.

\section{Conclusion}

In sum, as my statistical analysis revealed, grants for regional revitalisation policies are distributed to local municipalities where population decreases, local finances worsen and the unemployment ratio rises. Moreover, the distribution of grants for re-gional revitalisation policies does not apply to theories of preceding studies about the distribution of grants-in-aid in Japan; that is, they are distributed politically.

However, following my statistical analysis, the following question is pertinent: is there no variable which influences the distribution of grants for regional revitalisation policies other than finance trends and social and economic trends in local municipalities? The influence of employees assigned from central government ministries and agencies to local municipalities may be another variable which affects the distribution of grants. This issue must be pursued in future research. 


\section{Munenori Ichishima: Current Status of and Challenges in Regional Policies in Japan}

\section{Bibliography}

Centre of Area Studies in Hosei University and Yoshiyuki Okamoto eds. 2017. Chiiki Kasseika to Innovation -EU Syuyokoku no Jirei Kenkyu-. Huyoshobosyuppan.

Chiu, Hon-yee. 1993. Nihon no Rieki Bunpai Seisaku to Jiminto no Shihai. Senkyo Kenkyu, vol. 8, pp. 66-84.

Doi, Takero. 2000. Chiho Zaisei no Seijikeizaigaku. Toyokeizaisinposya.

Doi, Takero and Masahiro Ashiya. 1997. Kokkosisyutsukin Bunpai to Seiken Yoto tono Kankei. Nihon Keizai Kenkyu, Vol. 34, pp. 180-195.

Fujimoto, Yukio, et al. 1983. Yosan Haibun to Seijiteki Yoso. Kokyo Sentaku no Kenkyu, Vol. 3, pp. 56-67.

Hashimoto, Koshi ed. 2015. Chiho Sousei no Riron to Jissen -Chiiki Kasseika System Ron-. Soseisya.

Hori, Kaname. 1996. Nihon Seiji no Jissyo Bunseki. Tokai University Press.

Kaneko, Isamu. 2016. Chiho Sousei to Shometsu no Syakaigaku -Nihon no Community no Yukue-. Minervashobo.

Kobayashi, Yoshiaki. 1997. Gendai Nihon no Seiji Katei. University of Tokyo Press.

Nakato, Yasutoshi. 2016. Kaso Chiiki Saisei no Senryaku -Chiho Sousei kara Chiho Saisei he-. Daigakukyoikusyuppan.

Nakayama, Toru. 2016. Jinko Gensyo to Chiiki no Saihen -Chiho Sousei $\cdot$ Renkei Chukaku Toshiken · Compact City. Jichitaikenkyusya.

Onizuka, Naoko. 1997. Seihu no Hojokin Haibun ni okeru Seijiteki Youso ni tsuite. Hogaku Seijigaku Ronkyu, Vol. 33, pp. 297-318.

Takayose, Shozo. 2015. "Chiho Sousei" de Chiho Syometsu ha Soshi Dekiruka Chiho Sousei Saku to Hojokin Kaikaku-. Kojinnotomosya.

The Asahi Shimbun Company. 2014. Asahi Shimbun de Miru 2014 Sosenkyo no Subete. The Asahi Shimbun Company.

Yaoita, Shunpei. 2017. Chiho Sousei no Sogoseisakuron. Keisoshobo. 